\title{
TEACHING OF THE RESEARCH ACTIVITY OF THE FUTURE SPECIALISTS IN AG- RICULTURAL ENGINEERING DURING THE STUDYING OF AGRICULTURAL MA- CHINERY: PROBLEMS AND THEIR SOLVINGS
}

Butsyk I. M., Candidate of Pedagogical Sciences, Associate Professor of the Department of Pedagogy

National University of Life and Environmental Sciences of Ukraine

E-mail: i_butsyk@ukr.net

ORCID 0000-0002-3105-2802

\begin{abstract}
This article deals with the generalized results of the researches in terms of the development of research competence of future specialists in agricultural engineering. Besides, the article covers the basic problems of the organization of studying process of students that are connected with the research activity during the process of studying agricultural machinery. There are: characterized the results of students' polls and offered the ways of effective organization of studying in research activity.
\end{abstract}

Key words: research activity, teaching, methodical system, specialists in agricultural engineering, agricultural machinery.

Introduction. In modern economic processes, the characteristic specific feature of agro-industrial production is the constant focus on development, which takes place under the conditions of introduction of new technical devices, technologies, means, and forms of management. Under the conditions of such dynamic changes, one of the determinative figures at the production is the specialists, the effectiveness of the industry itself depends on their effective professional activity. Therefore, the current priorities of higher education in Ukraine are a clear focus on highquality training of specialists, based on the formation of their high level of professional competence, which will become the basis of successful professional activity and competitiveness.

An expert in agricultural engineeringis a significant person in the organizational processes of agrarian production. His/ her current engineering activities involve the pursuit of professional tasks in work with techniques and technology, a significant proportion of which is to work with agricultural machines. Generally, the main task of the agrarian engineer is to ensure the effective operation of the technique with the appropriate technology. Such activity is based on the study, development, and introduction into agrarian production of agricultural equipment through the implementation of constructive, analytical, prognostic, design, technological, research, management, maintenance, and repair work. In turn, this requires the formation of a high level of research competence of agrarian engineers. Therefore, this condition has directed our further research towards studying the problem of qualitative training of future specialists in the specialty " Agricultural engineering" within the framework of the organization of effective study of agricultural machines that allows developing their research competence.

First of all, the effectiveness of specialists training depends on the effective organization of the educational process, based on the proper construction and implementation of effective methodological training systems. One 
of such systems is considered a methodical system of research competence development of future specialists in agricultural engineering in the process of studying agricultural machines. Based on preliminary studies, we have proposed a conceptual, methodological system that is an ordered set of interconnected subsystems that function through the purposeful implementation of teaching methods and technologies aimed at preparing a future specialist for professional research activities [2]. As a result of the accomplished scientific work, we faced the need to develop a model of a methodological system that would allow developing the research competence of students of the specialty "Agro-engineering" in the process of studying agricultural machinery. This requires the identification of existing problems of the effective organization of teaching students of research work, based on this it is necessary to identify the solutions to these problems.

Analysis of recent researches and publications. Currently, the scientific theory is rich in various studies within the scope of solving the problem of training engineering personnel in Ukraine and abroad. Today, in the world pedagogical science, studies of the problem of professional training of engineering personnel are widely covered (O. Antonov, I. Berokina, T. Bilousova, I. Bytynas, N. Holovyn, V. Holovko, O. Dzhedzhula, S. Zelinskyi, H. Krasylnykova, Ya. Krupskyi, M. Lazariev, I. Markhel, O. Romanovskyi, O. Silchuk, I. Fedosova, D. Chernyshova, M. Shubas), in which researchers are almost not concerned with the problem of the formation of research competence. In the works on training technical and engineering personnel for agro-industrial production, this problem also does not find the necessary solution (I. Bendera, I. Blozva,
M. Bondar,
O. Voshchevska,

O. D'omin, N. Dotsenko, N. Ivanovskyi,
K. Kovalova, I. Kolosok, P. Luzan, V. Lukach, V. Manko, Yu. Nahirnyi, L. Pavliuk, V. Riabets, I. Uhryniuk).

Various organizational aspects of students training in research activity, which do not pay attention to the organization of research activities of future specialists in agricultural engineeringduring their study of agricultural machines, are currently considering by I. Abramova, E. Yelkina, Yu. Yerfort, V. Iskrytskyi, N. Naumkin, S. Podliesnyi, I. Yaniuk. In particular, A. Gorshkova solves the problem of improving the training of specialists in the oil and gas processing industry for research activities in the context of competence-oriented engineering education. The scientist has attempted to develop and implement a functional model of training for research activity based on the organization of a developing educational environment [4]. In the study, D. Salyamova emphasizes the ways of developing partnership relations between the state, scientific structures and educational institutions, which provides training of highly skilled personnel, in particular, to research professional activity [7]. S. Belkina defines the key requirements for the methodological support of the process of formation of the research competence of engineering students while teaching naturalscience disciplines, and she proves approaches to determining the content and application of methods and means of studying [1]. But in a number of these works, scientists do not solve the problem of effective organization of the training of future specialists in agricultural engineering for research activities when studying agricultural machinery.

In recent years, N. Golovin, A. Koshuk, E. Luhovska, O. Titova, and others point up the research on the problem of training specialists in agroengineering. For instance, N. Golovin substantiates and verifies the conditions for the formation of research skills 
of students of agro-technical institutes on disciplines of the natural-mathematical cycle in the process of solving problems of professional content [3]. O. Koshuk specifies pedagogical conditions of professional training of future engineers of agrarian production from the standpoint of system approach and modernization, based on which distinguishes ways of their provision [5]. O. Titova substantiates pedagogical conditions of potential creative development of future engineers of agrarian profile [8]. E. Luhovska distinguishes pedagogical conditions of professional competence formation of techniciansmechanics of agro-industrial production [6]. But in the works mentioned above, the problem of determining the ways of effective organization of students training of research activities during the study of their discipline "Agricultural Machines" is not resolved.

Purpose. The purpose of our study was to determine the ways of effective organization the students training of research activities while studying agricultural machines.

Methods: theoretical (analysis, synthesis, search-bibliographic method, comparison, generalization and systematization for the study of pedagogical literature and scientific articles on the training of agricultural engineers, the formation and development of research competence of specialists, the organization of training research activities; cluster analysis, generalization and synthesis for grouping of factors by typical features); empirical (poll - to identify factors that complicate the educational work of students); statistical and mathematical (ranking, methods of survey findings processing, nonparametric techniques, calculation methods of aggregated estimates for summarizing, presenting and confirming of the results obtained in the poll).
Results. One of the main tasks of modern education is to provide special conditions in the educational environment, which are created based on the optimal impact on the personality of certain factors that are necessary and sufficient to achieve the desired result. The analysis of the state and the level of theoretical and methodological development of issues of forming the research competence of future specialists in agro-engineering, the results of their practical implementation in institutions of higher education and the real state of training of agricultural engineers in our state allowed us to identify common problems of research competence: education management problems, learning content problems, problems in teaching methods and professional pedagogical activity of teachers, problems in motivating students and their learning activities. Based on the study, several unresolved issues were identified, which are in several contradictions between:

- the need for a society in engineering personnel for agro-industrial production, who ready to perform professional research activity in work with agricultural machines, and insufficient development of theoretical and methodological aspects of their training;

- the need to create a methodological system of the development of research competence of specialists in agricultural engineeringin an institution of higher education and the lack of conventional methodological approaches to the formation of their research competence in the process of agricultural machines studying;

- necessity and the present level of research competence of graduates of the specialty "Agro-engineering";

- the awareness of future specialists in agricultural engineering of the necessity and significance of research competence and their insufficient formation; 
- the existing reproductive character of training agricultural engineers and the innovative nature of engineering activity in working with agricultural machines;

- the potential possibilities of the pedagogical process in institutions of higher education towards the development of research competence of specialists in agricultural engineering in the process of studying agricultural machines and traditional teaching methods.

An important prerequisite for effective modern education is the correct identification of all problems that impede the effective training of specialists. This issue in the future become the basis for the development and implementation of the fundamental ways to an effective organization the educational process, will create the optimal influence on the nature of certain factors that are necessary and sufficient to achieve the planned result. Therefore, to substantiate the required ways of effective organization of the students research activity training during in the study of agricultural machinery, 38 factors were identified that impede their academic work and hinder the effective training of students for research work.

These factors were determined based on the poll method. Further, using cluster analysis, we reduced all the determining factors in the poll to four homogeneous groups according to their typical leading signs: factors of learning content; motivational factors; factors of educational abilities of the person; elements of the educational process organization. The results obtained in the poll were tested by methods of mathematical statistics, which allowed us to confirm the final results of generalized aggregate estimates.

As a result of the interview, it was discovered that each student experiences difficulties in carrying out research tasks during training and individual work. The obtained results of the interview showed (Fig. 1) that: $9 \%$ of students are dominated by factors of personal educational abilities (ability to organize their own education; lack of formation of abilities to explore, independently search, summarize and present information, etc.); the factors of the content of learning (the difficulty and complexity of the contents of the educational material and educational tasks) are dominated by $13 \% ; 24 \%$ of students are dominated by motivational factors (the lack of relevance of educational and research tasks in the further professional activity; the lack of relevance of the discipline in the preparation of a specialist in this specialty; the relevance of this specialty on which a student is forced to study; the lack of interest and desires to perform educational and research tasks; the desire for a student to study constantly and intensely).

$54 \%$ of the interviewed students got the following dominant factors of the organization of the educational process (fig. 2): $5 \%$ of the students hindered the effective performance of research tasks by the lack of information and literary sources; $9 \%$ have an absence or insufficiency of time; $10 \%$ of the students have the didactically ineffective organization of educational process by teacher; $12 \%$ have the discrepancy between the contents of the research work and the purpose of the educational topic; $18 \%$ have didactically ineffective organization of educational work in the system of training classes 
factors of the organization of the educational process

motivational factors

factors of educational abilities of the person

factors of learning content

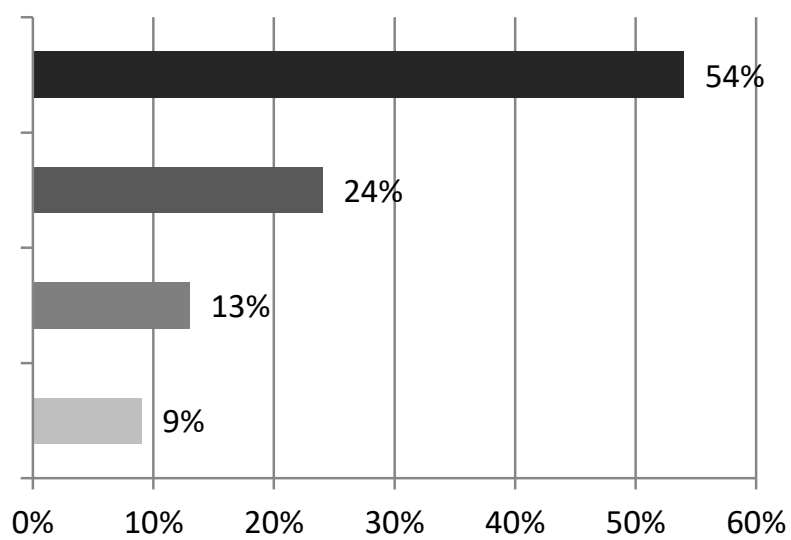

Fig. 1. Diagram of the distribution of the factors that impede the students' educational work while carrying out research tasks (according to the results of the interview of students of the specialty "Agroengineering")

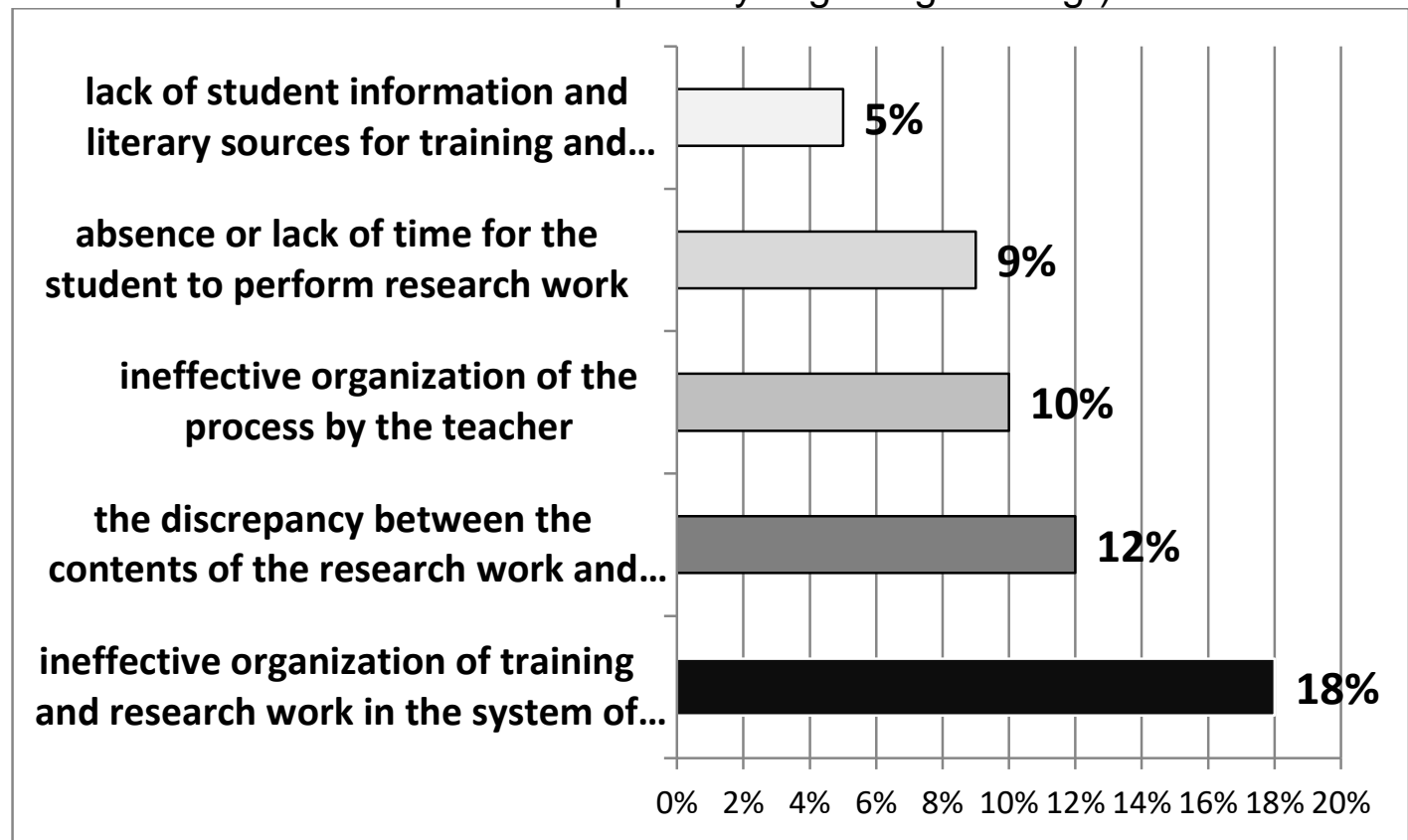

Fig. 2. Diagram of distribution of factors from the group of organization of educational process that prevents the students' training work during research tasks (according to the results of the interview of students of the «Agroengineering» specialty )

Consequently, based on the results obtained in the interview, it was found that a number of problems based on the didactically imperfect organization of the classroom and independent work, the selection and structuring of the content of teaching material and research tasks, the lack of ability to manage time, and so on became a hedge for effective training management. This directed our further work toward identifying ways of effectively organizing training for students in research activities while studying them agricultural machines in accordance with previously scientifically grounded conceptual foundations: methodological approaches, developed content of purposeful development of research competence, scientific concept of problem-solving, methodical system of development the research competence of future specialists in agroengineering in the process of studying of agricultural machines.

Problem 1 is an ineffective organization of training and research work in the system of training activities, in our opinion, can 
be solved with the help of providing the introduction of step-by-step and practice-oriented processes in the study of agricultural machines. The step-by-step process involves the purposeful organization of training activities of students with their gradual development on the basis of a permanent transition from theoretical to practical training and their involvement in training and research work. The practice-oriented process is ensured by the purposeful and permanent inclusion of students in solving of training and research tasks in training and production conditions within the framework of studying, developing and introducing into agrarian production of agricultural machinery and technologies during the execution of engineering, analytical and forecasting, design, technological, research, management, maintenance and repair works.

Implementation of step-by-step and practical-oriented processes in the study of agricultural machines can occur in the following ways:

1) Organization of step-by-step training activities of students at the expense of the consistent application of methods and means of training, methods and means of diagnosing of training results, content of training material in the following basic forms of work: individual work, lectures, practical classes, laboratory works, course designing, industrial practice, reporting conferences, Bachelor qualification work.

2) Organization of practice-oriented training through theoretical and practical training in the areas of training and researching of real production processes and problems in the following main forms of work: informational and problem lectures, binary lectures, problem lectures using project technologies, field training sessions, simulation and game designing, course and diploma designing, scientific and practical conferences, scientific and practical seminars, problem seminars, webinars, round tables, thematic excursions to production and research institutions, hobby groups students' activity.

Problem 2 is inconsistency of the content of research work with the purpose and objectives of the topic, from our point of view, can be solved via providing the introduction of purposeful construction of the content of training for agricultural machines on the basis of the permanent integration of scientific knowledge and production processes with optimal coordination with the content of vocational training, which is occurred in: the formation and implementation of interdisciplinary connections; consecutive and optimal combination of theoretical and practical training, training and research work of students; the choice and application of content, methods, tools and forms of training.

Solving this problem can occur in the following ways:

1) Pedagogical integration, consisting of a specially organized organic combination of content with the forms, methods and means of teaching in the methodical system of training for agricultural machines and beyond, which leads to the gradual development of the personality of a future specialist.

2) Purposeful choice of the content of training, consisting of specially

organized preparation and structuring of the initial material, based on the following specific principles: compliance with the stages of training; individualization of training (individual psychic peculiarities, motives, interests, profile orientation); differentiation of training material; taking into account the development of science and technology; taking into account the development of the economy, agricultural production, social relations and the requirements of today's employer; compliance with methods, forms and means of training and opportunities for their effective application; taking into account the difficulty and complexity of the educational material; information accessibility of training content.

Problem 3 is an ineffective organization of the educational process by the teacher, in our opinion, can be solved by:

1) Ensuring a holistic pedagogical process in the study of agricultural machines in particular, and the training of specialists in general, due to the support of the following principles: the unity of training and 
upbringing; the unity of the methodical system of training and the system of vocational training; the unity of all components of the methodological system (purpose, content, methods, forms and means of training and diagnostics); combination of classroom and individual work of students; the unity of theoretical and practical training; an optimal combination of educational work with students' training and research activity; effective interaction between the teacher and the student; Individualization of training in conjunction with collective educational activity of students; systematic and consistent training.

2) Ensure simulation of professional research activity in the process of the study of agricultural machines, which consists in the systematic application in the educational process of the complex of educational and research tasks in an organic way, combined with their content, methods, means of study and research methodology during the organization of training sessions, individual work, course and diploma designing, production practices, as well as forms of research work of students

Consequently, based on the results obtained in the study, we have constructed a generalized structural model for solving problems that prevent students' training work in research work in the process of studying agricultural machines (fig. 3).
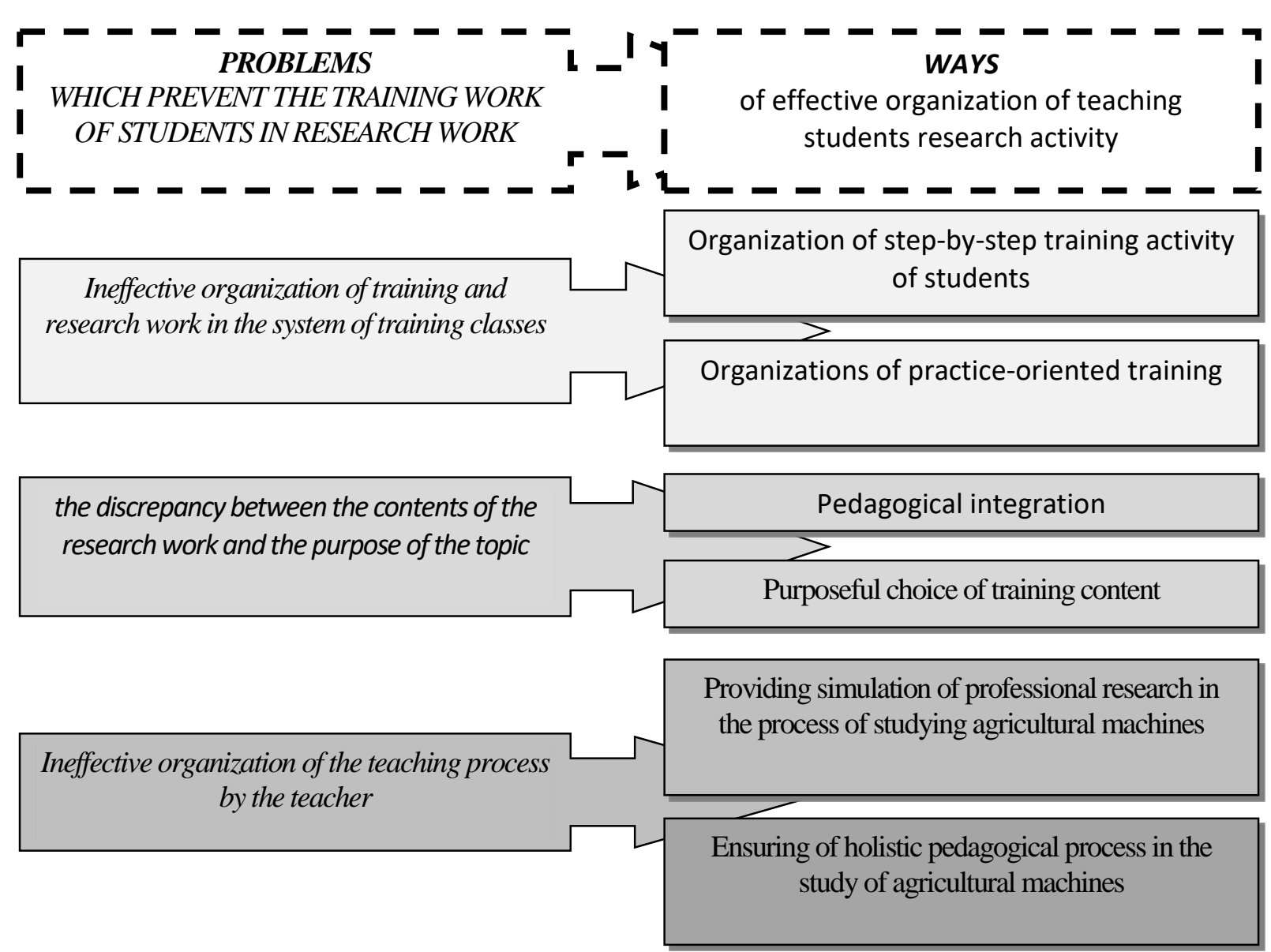

Fig. 3. The generalized structural model for solving problems that prevent the training work of students in research work in the process of studying agricultural 
Conclusions and perspectives (Discussion). On the basis of our research, we identified the main problems of organizing training for students in the specialty "Agroinengineering" in the study of agricultural machines. The obtained results allowed to substantiate the ways of effective organization of training of students of research activity, which will become the basis for solving these problems. To the ways of effective organization of teaching students research activities in the process of studying agricultural machines, we assigned: the organization of step-by-step educational activities of students, the organization of practical training, pedagogical integration, targeted selection of training content, ensuring the simulation of professional research activities in the study of agricultural machines, the provision of a holistic pedagogical process.

The priority direction of further work is the study of the problem of improving educational processes in the direction of developing training methods aimed at forming the research competence of a specialist in agroengineering in the process of studying agricultural machines.

\section{References}

\section{Byelkina, S.D.} Formuvannya doslidnyts'koyi kompetentnosti maybutnikh inzheneriv $u$ protsesi vykladannya navchal'nykh dystsyplin tsyklu pryrodnycho-naukovoyi pidhotovky [Formation of research competence of future engineers in the process of teaching the disciplines of the cycle of natural science training]. Profesiyna osvita. Naukovi zapysky. Seriya: pedahohika, vol. 3, P.19-25.

2. Butsyk, I.M. (2017). Metodychna systema formuvannia doslidnytskoi kompetentnosti inzheneriv ahrarnoho profiliu [Methodical system of formation of research competence of engineers of agrarian profile]. Naukovyi visnyk Mykolaivskoho natsionalnoho universytetu imeni V.O.Sukhomlynskoho, Mykolaiv, vol. 3(58), P. 5054.

3. Holovyn N.M. (2007). Formuvannia doslidnytskykh umin $z$ dystsyplin pryrodnycho-matematychnoho tsyklu v studentiv ahrotekhnichnoho instytutu v protsesi fakhovoi pidhotovky [Formation of research skills in the disciplines of the natural-mathematical cycle at the students of the agrotechnical institute in the process of vocational training]. Ternopilskyi nats. ped. universytet im. Volodymyra Hnatiuka, Ternopil, $20 \mathrm{p}$.

4. Gorshkova, O.O. (2017). Podgotovka studentov $\mathrm{k}$ issledovatelskoy deyatelnosti v kontekste kompetentnostnoorientirovannogo inzhenernogo obrazovaniya [Preparation of students for research in the context of competence-oriented engineering education]. $394 \mathrm{p}$.

5. Koshuk, O. (2017). Systemnyi pidkhid do modernizatsii pidhotovky maibutnikh inzheneriv ahrarnoho vyrobnytstva [System approach to modernization of training of future engineers of agrarian production]. Pedahohichni nauky, vol. 68, P. 51-61.

6. Luhovska, E.M. (2013). Pedahohichni umovy formuvannia fakhovoi kompetentnosti tekhnikiv-mekhanikiv ahropromyslovoho vyrobnytstva [Pedagogical conditions of formation of professional competence of technicians-mechanics of agro-industrial production]. Pedahohika i psykholohiia profesiinoi osvity, vol. 6, P. 111-120.

7. Salyamova, D.R. (2009). Stimulirovanie razvitiya nauchnoissledovatelskoy deyatelnosti $v$ vyisshem uchebnom zavedenii [Stimulation of the development of research activities in the higher educational institution]. Moskva, 210 p.

8. Titova, O.A. (2018). Pedahohichni umovy rozvytku tvorchoho potentsialu maibutnikh inzheneriv ahrarnoho profiliu [Pedagogical conditions of creative potential development of future engineers of agrarian profile]. Naukovyi chasopys Natsionalnoho pedahohichnoho universytetu imeni M.P.Drahomanova. Seriia 5: Pedahohichni nauky: realii ta perspektyvy. vol. 65, P. 100-103.

\section{Список використаних джерел}

1. Бєлкіна С.Д.Формування дослідницької компетентності майбутніх інженерів у процесі викладання навчальних дисциплін циклу природничо-наукової підготовки. Профресійна освіта. Наукові записки. Серія: педагогіка. 2015. №3. C.19-25 
2. Буцик I.М. Методична система формування дослідницької компетентності інженерів аграрного профрілю. Науковий вісник Миколаївського національного університету імені В.О.Сухомлинського. 2017. Вип. 3(58). С. 5054.

3. Головин Н. М. Формування дослідницьких умінь 3 дисциплін природничо-математичного циклу в студентів агротехнічного інституту в процесі фрахової підготовки: автореф. дис. д-ра пед. наук: 13.00.04 / Тернопільський нац. пед. університет ім. Володимира Гнатюка. Тернопіль, 2007. 20 с.

4. Горшкова О. О. Подготовка студентов к исследовательской деятельности в контексте компетентностно-ориентированного инженерного образования: дис... д. пед. наук: 13.00.08. Москва, 2017. 394 c.
5. Кошук О. Системний підхід до модернізації підготовки майбутніх інженерів аграрного виробництва. Педагогічні науки. 2017. Вип. 68. С. 51-61.

6. Луговська Е. М. Педагогічні умови фрормування фрахової компетентності техніків-механіків агропромислового виробництва. Педагогіка і психологія профресійної освіти. 2013. Вип. 6. C. 111-120.

7. Салямова Д. Р. Стимулирование развития научно-исследовательской деятельности в высшем учебном заведении: дис. ... канд. эконом. наук: 08.00.05. Москва. 2009. 210 с.

8. Тітова О. А. Педагогічні умови розвитку творчого потенціалу майбутніх інженерів аграрного профілю. Науковий часопис Національного педагогічного університету імені М. П. Драгоманова. Серія 5: Педагогічні науки: реалії та перспективи. 2018. Вип. 65. С. 100-103

\section{НАВЧАННЯ ДОСЛІДНИЦЬКІЙ ДІЯЛЬНОСТІ МАЙБУТНІХ ФАХІВЦІВ 3 АГРОІНЖЕНЕРІЇ ПІД ЧАС ВИВЧЕННЯ СІЛЬСЬКОГОСПОДАРСЬКИХ МАШИН: ПРОБЛЕМИ ТА ШЛЯХИ ЇХ ВИРІШЕННЯ}

Буцик I. M.

Анотація. У статті подано узагальнені результати досліджень з питань формування дослідницької компетентності майбутніх фрахівців з агроінженерії, на основі яких було запропоновано шляхи ефективної організації навчання. Дослідження передбачало проведення опитування студентів з метою визначення низки фракторів, що утруднюють їх навчальну роботу під час виконання навчальних дослідницьких завдань. Результати опитування охарактеризовано та унаочнено у діаграмі розподілу утруднюючих фракторів та діаграмі фракторів з організації навчального процесу, яка, на думку респондентів, найбільш утруднює навчальну роботу студентів під час виконання ними дослідницьких завдань. На основі отриманих та узагальнених результатів опитування було визначено та схарактеризовано основні проблеми організації навчання дослідницькій діяльності студентів спеціальності "Агроінженерія», зокрема й при вивченні ними сільськогосподарських машин. Це надало змогу запропонувати та схарактеризувати шляхи ефективної організації навчання студентів дослідницькій діяльності, що полягають у: упровадженні поетапно-діяльнісного та практико-орієнтованого процесів при вивченні сільськогосподарських машин; педагогічній інтеграції; цілеспрямованому доборі змісту навчання; забезпеченні цілісного педагогічного процесу; забезпеченні імітації професійної дослідницької діяльності під час вивчення сільськогосподарських машин. На основі отриманих у дослідженні результатів було побудовано узагальнену структурну модель вирішення проблем, що утруднюють навчальну роботу студентів у дослідницькій роботі у процесі вивчення сільськогосподарських машин.

Ключові слова: дослідницька діяльність, навчання, методична система, фрахівець з агроінженерії, сільськогосподарські машини. 